\title{
BIOLOGY OF Bemisia tabaci (GENN.) B-BIOTYPE AND PARASITISM BY Encarsia formosa (GAHAN) ON COLLARD, SOYBEAN AND TOMATO PLANTS
}

\author{
Karina Manami Takahashi1 ${ }^{1}$ Evoneo Berti Filho²*; André Luiz Lourenção ${ }^{3}$ \\ ${ }^{1}$ USP/ESALQ - Programa de Pós-Graduação em Entomologia. \\ USP/ESALQ - Depto. de Entomologia, Fitopatologia e Zoologia Agrícola, C.P. 09, 13418-900 - Piracicaba, SP - \\ Brasil. \\ IAC, C.P. 28 - 13001-970 - Campinas, SP - Brasil. \\ *Corresponding author <eberti@esalq.usp.br>
}

ABSTRACT: The silverleaf whitefly Bemisia tabaci (Genn.) B-biotype (= B. argentifolii) (Hemiptera: Aleyrodidae) is a polyphagous insect attacking many plant species of economic importance. A comparison study was conducted on the duration of the egg-to-adult period, and the percentage of hatching eggs of Bemisia tabaci (Genn.) B-biotype on collard (Brassica oleracea L. var. acephala D.C.), soybean (Glycine $\max ($ L.) Merr.) and tomato (Lycopersicon esculentum Mill.) plants, as well as the egg-to-adult period of Encarsia formosa (Gahan) on the $1^{\text {st }}, 2^{\text {nd }}, 3^{\text {rd }}$ and $4^{\text {th }}$ whitefly nymphal instars on these three plant species. The experiments were conducted in a laboratory $\left(25^{\circ} \mathrm{C}, 70 \pm 10 \% \mathrm{RH}, 14\right.$-hour photophase). The duration of the egg-to-adult period of B. tabaci was 19.8 days on collard, 21.2 days on soybean and 22.0 days on tomato. The number of hatched eggs was higher on collard when compared to soybean and tomato plants. Concerning E. formosa regardless of plant species, the duration for the egg-to-adult period was shorter for the $3^{\text {rd }}$ and $4^{\text {th }}$ instar nymphs as compared with the other instars.

Key words: Hymenoptera, Aphelinidae, Hemiptera, Aleyrodidae, silverleaf whitefly

\section{ASPECTOS BIOLÓGICOS DE Bemisia tabaci (GENN.) BIÓTIPO B E PARASITISMO POR Encarsia formosa (GAHAN) EM COUVE, SOJA E TOMATEIRO}

\begin{abstract}
RESUMO: A mosca branca Bemisia tabaci (Genn.) biótipo B é uma praga polífaga que ataca muitas culturas de importância econômica. O controle químico pode causar problemas como o aparecimento de resistência nesse inseto, resíduos nos produtos das culturas, ou mesmo poluição ambiental. Um método alternativo seria o controle biológico, com o parasitóide Encarsia formosa (Gahan), o mais usado contra moscas brancas a nível mundial. Avaliaram-se o tempo de desenvolvimento de ovo a adulto e a porcentagem de ninfas eclodidas de B. tabaci (Genn.) biótipo B em couve (Brassica oleracea L. var. acephala D.C.), soja (Glycine max (L.) Merr.) e tomateiro (Lycopersicon esculentum Mill.), bem como o desenvolvimento de ovo a adulto de E. formosa em ninfas de $1^{\circ}, 2^{\circ}, 3^{\circ}$ e $4^{\circ}$ ínstares dessa mosca-branca nessas três espécies vegetais. Os experimentos foram desenvolvidos em laboratório, a $25^{\circ} \mathrm{C}, 70 \pm 10 \%$ UR e 14 h de fotofase. O tempo de duração ovo-adulto de $B$. tabaci biótipo B foi mais curto em couve (19,8 dias) e mais longo em tomateiro (22,0 dias), ficando a soja (21,2 dias) em posição intermediária. A couve mostrou também a maior porcentagem de ninfas eclodidas comparativamente à soja e ao tomateiro. Com relação a E. formosa, independentemente da planta, o período ovo-adulto foi menor em ninfas de $3^{\circ}$ e $4^{\circ}$ ínstares, demonstrando que esse parasitóide se desenvolve melhor em ninfas mais desenvolvidas.

Palavras-chave: Hymenoptera, Aphelinidae, Hemiptera, Aleyrodidae, mosca-branca
\end{abstract}

\section{INTRODUCTION}

The silverleaf whitefly Bemisia tabaci (Genn.) B-biotype (= B. argentifolii) (Hemiptera: Aleyrodidae) is a polyphagous insect attacking many plant species of economic importance, such as vegetables, oil and ornamental plants (Oliveira et al., 2001). The intensive use of chemicals in crop management, together with the high reproductive potential of this insect are considered the reasons why $B$. tabaci B-biotype reached the status of important pest species (Brown et al., 1995). According to Lima et al. (2000), B.tabaci is known as a pest problem in all of the Brazilian states.

Chemical control (mainly with neonicotinoids and insect growth regulators) is currently the method available. However, the prevalent use of these insecti- 
cides may cause problems related to insect resistance, environmental pollution and residues in crop products. These concerns have led to alternative methods of control, including the biological control of B. tabaci with the parasitoid Encarsia formosa (Gahan) (Hymenoptera: Aphelinidae). This parasitoid is probably the most worldwide used for the control of Trialeuroides vaporariorum (Westwood) and Bemisia spp. in greenhouses (Hoddle et al., 1998). However, there is limited information on the laboratory rearing of this beneficial insect (Hu et al., 2002). Biological parameters are important to ascertain the role of natural enemies in the management of recently introduced pest species mainly when focusing on their natural enemies. Therefore, the objectives of this research were to determine the duration of the egg-to-adult developmental period and the percentage of hatching eggs of B. tabaci Bbiotype on collard, soybean and tomato plants, as well as the egg-to-adult period of E. formosa (Gahan) on the $1^{\text {st }}, 2^{\text {nd }}, 3^{\text {rd }}$ and $4^{\text {th }}$ whitefly nymphal instars on these three plant species.

\section{MATERIAL AND METHODS}

\section{Biological parameters of $B$. tabaci B-biotype}

A whitefly population of $B$. tabaci B-biotype, previously identified by Dr. Judith K. Brown, University of Arizona, USA, was provided by the "Instituto Agronômico de Campinas (IAC)", São Paulo, Brazil. This population was then maintained on poinsettia in a greenhouse protected by a $0.2 \times 0.2 \mathrm{~mm}$ mesh screen. Plants of soybean (cultivar IAC-15), tomato (cultivar Santa Clara) and collard (30 cm high) were infested with 30 adults of $B$. tabaci B-biotype per plant. The insects were collected by aspirating them with a straw with one of the ends closed with cotton.

A total of 30 plants of each species were infested and maintained in plastic cages (plastic pet covered with voile). After 24 hours the leaves containing 30 eggs of B. tabaci B-biotype were cut in discs (40 $\mathrm{mm}$ diameter) which were placed on top of an agar + nipagin layer in plastic dishes $(60 \times 20 \mathrm{~mm})$ with a lid on top. The duration of the egg-to-adult period and the number of hatched eggs on each plant species were evaluated in laboratory conditions $\left(25^{\circ} \mathrm{C} ; 70 \pm 10 \% \mathrm{RH}\right.$; 14-hour photophase). A randomized experimental design was set up with the parcel represented by one plant of each host species with 30 replications. The results were subjected to the analyses of variance and the means were compared by the Tukey's test $(p \leq 0.05)$.

\section{Biological parameters of $E$. formosa on $B$. tabaci B-biotype}

One couple (a male and a female) of $E$. formosa was placed in each plastic dish $(60 \times 20 \mathrm{~mm})$ for a 24 hour period, with 30 replications for each nymphal instar of B.tabaci B-biotype on all the plants tested. The dishes were maintained in laboratory conditions $\left(25^{\circ} \mathrm{C} ; 70 \pm 10 \% \mathrm{RH}\right.$; 14-hour photophase). The life cycle of $E$. formosa parasitizing the four nymphal instars of $B$. tabaci B-biotype was evaluated daily. The percentages of parasitism were evaluated for whiteflies on each plant species. The experimental design was a randomized factorial scheme $(4 \times 3)$ with 30 replications. The treatments were the nymphal instars of B. tabaci B-biotype on collard, soybean and tomato plants. To determine the effect of each factor, the analysis of variance ( $\mathrm{F}$ test; $p \leq 0.05$ ), was performed and the means between the nymphal instars of the pest and the plant species were evaluated by using the Tukey's test $(p=0.05)$.

\section{RESULTS AND DISCUSSION}

\section{Developmental time of B.tabaci B-biotype}

The developmental time from egg-to-adult of Bemisia tabaci B-biotype was 19.8 days on collard, 21.2 days on soybean and 22.0 days on tomato (Table 1). Simmons (2002) evaluated five host plant species of B. tabaci B-biotype and observed that collard was the most attractive among those species for nymphs to establish and feed. That information supports our results that collard provided a shorter egg-to-adult cycle and is a good host plant for the development of this whitefly. Salas \& Mendoza (1995) reported that the egg-to-adult period of B. tabaci on tomato leaves at $25^{\circ} \mathrm{C}$ and $65 \% \mathrm{RH}$ is 22.3 days, which is a similar value to that observed in our research (22.0 days). Conversely, Villas-Bôas et al. (2002) reported the devel-

Table 1 - Time (days) of egg-adult development $( \pm$ EP) of B. tabaci B-biotype and egg hatching $(\%)( \pm \mathrm{EP})$ on collard, soybean and tomato plants $\left(\mathrm{T}=25^{\circ} \mathrm{C} ; \mathrm{RH}=70 \pm 10 \% ; 14\right.$ - hour photophase).

\begin{tabular}{lccc}
\hline \multirow{2}{*}{ Stage } & \multicolumn{3}{c}{ Host plant } \\
\cline { 2 - 4 } & Collard & Soybean & Tomato \\
\hline Egg-adult $^{1}$ & $19.8 \pm 0.39 \mathrm{c}$ & $21.2 \pm 0.29 \mathrm{~b}$ & $22.0 \pm 0.32 \mathrm{a}$ \\
Egg hatching $^{1}$ & $90.2 \pm 19.06 \mathrm{a}$ & $72.0 \pm 10.27 \mathrm{~b}$ & $63.9 \pm 8.22 \mathrm{~b}$ \\
\hline
\end{tabular}

${ }^{1}$ Means followed by the same letter in rows do not differ (Tukey's test, $p \leq 0.05$ ). 
opmental period as 27.5 days at $25^{\circ} \mathrm{C}$ for $B$. argentifolii (= B. tabaci B-biotype). On the other hand, Coudriet et al. (1985) reported this period as 27.3 days when B. tabaci was reared on tomato leaves at $26.7^{\circ} \mathrm{C}$. Our value for the developmental time of $B$. tabaci B-biotype on soybean leaves (21.2 days) was similar to that obtained by Albergaria \& Cividanes (2002) who observed 70.9 days at $15^{\circ} \mathrm{C}, 21.8$ days at $30^{\circ} \mathrm{C}$, and $64 \%$ and $90 \%$ viability, respectively.

The mean number of whitefly nymphs on collard was higher than those observed for soybean and tomato, although the values did not differ between them (Table 1). Collard was the host plant on which B. tabaci presented the lowest life cycle (19.8 days) and the highest mean number of hatched eggs (90.2). Also, this species provided the longest durability. Therefore, this plant is the most suitable among the ones tested for the development of B. tabaci B-biotype when dealing with laboratory rearing of this whitefly.

\section{Biological features of $E$. formosa on B. tabaci B- biotype}

The period of egg-to-adult of E. formosa on the first and second whitefly instars did not differ, either on collard or on tomato plants (Table 2). However, on the soybean plant the developmental period on the first instar nymph was higher than the observed on the second instar (Table 2). This period was higher on third instar nymphs when compared to fourth instar ones on collard plants, but no difference was observed on soybean and tomato concerning these two instars. Among the three plant species, the egg-to-adult periods of E. formosa were shorter on third and fourth instar nymphs, thus indicating a better performance for development of this parasitoid on these nymphal instars of B. tabaci B-biotype.

Regarding the first and second instar nymphs, the egg-to-adult periods on collard and on tomato plants were lower than that observed on soybean plants. In all of the evaluated plant species no difference was detected in the egg-to-adult periods of $E$. formosa on third instar nymphs of B. tabaci B-bio- type. However, on fourth instar nymphs, the developmental period on collard was lower than those observed on soybean and tomato plants, but no difference was detected between these two last ones.

Because different tritrophic interactions were involved, it is not fair to make a direct comparison between our results with those obtained from studies dealing with different species of whiteflies and host plants. The developmental period of E. formosa parasitizing the four nymphal instars of $T$. vaporariorum at $25^{\circ} \mathrm{C}$ was 15 days on tobacco (Arakawa, 1982) and 15 days on tomato plants (Burnett, 1949). The eggto-adult period of Encarsia transversa on B. tabaci at $15^{\circ} \mathrm{C}$ and $30^{\circ} \mathrm{C}$ and 70 to $75 \% \mathrm{RH}$, ranged from 11.3 to 15.1 days for the females and from 12.1 to 14.6 days for the males (Anthony et al., 2003).

Woets \& Lenteren (1976) reported that the control of $T$. vaporariorum by the parasitoid $E$. formosa was highly efficient on tomato and red pepper plants, fairly efficient on egg-plant, but less efficient on cucumber plants. They suggested that such results might be due to plant unsuitability for the development of the whitefly immature stages and/or the characteristics of plant leaf surface influencing the parasitoid searching ability. So, notwithstanding the cucumber being a good host plant for $T$. vaporariorum, it seems that its leaves are less suitable for the parasitoid searching ability. Based on the results of our research on nymphs of B. tabaci B-biotype, the suggestion of Woets \& Lenteren (1976) may be applied to the soybean plants. Although it is a good host plant for the whitefly development, soybean seemed to be less suitable for E. formosa. This aspect should be of greatest importance for the parasitoid development, though the external morphology of the evaluated plants was not the scope of our research.

According to Soto et al. (2001), the egg-toadult period of E. formosa was long at low temperature $\left(29.5\right.$ days at $\left.14.6^{\circ} \mathrm{C}\right)$, but shortened as the temperature increased, reaching 10 days at $33.5^{\circ} \mathrm{C}$. Developmental time by this parasitoid on the third nymphal instar of $T$. vaporariorum was lower than that on the fourth instar, at the six temperatures evaluated.

Table 2 - Time (days) of the egg-to-adult period ( \pm EP) of E. formosa on first, second, third and fourth nymphal instars of B. tabaci B-biotype on collard, soybean and tomato plants $\left(\mathrm{T}=25^{\circ} \mathrm{C} ; \mathrm{RH}=70 \pm 10 \% ; 14\right.$-hour photophase $)$.

\begin{tabular}{lccc}
\hline \multirow{2}{*}{ Host instar } & \multicolumn{3}{c}{ Host plant } \\
\cline { 2 - 4 } & Collard & Soybean & Tomato \\
\hline $1^{\text {st }}$ & $16.03 \pm 0.13 \mathrm{bA}$ & $16.80 \pm 0.32 \mathrm{aA}$ & $16.30 \pm 0.47 \mathrm{bA}$ \\
$2^{\text {nd }}$ & $15.97 \pm 0.13 \mathrm{bA}$ & $16.27 \pm 0.39 \mathrm{aB}$ & $16.03 \pm 0.19 \mathrm{bA}$ \\
$3^{\text {rd }}$ & $15.03 \pm 0.19 \mathrm{aB}$ & $15.23 \pm 0.36 \mathrm{aC}$ & $15.10 \pm 0.18 \mathrm{aB}$ \\
$4^{\text {th }}$ & $14.10 \pm 0.36 \mathrm{bC}$ & $15.00 \pm 0.13 \mathrm{aC}$ & $14.83 \pm 0.28 \mathrm{aB}$ \\
\hline
\end{tabular}

Means followed by different capital letters in columns and lowercase letters in rows, differ from each other by Tukey's test $(p \leq 0.05)$. 
Those results suggest a better adaptation of the parasitoid to the third nymphal instar. However, in our research, no difference was observed on soybean and tomato plants as to that period of the parasitoid on third and fourth nymphal instars of B. tabaci $\left(25^{\circ} \mathrm{C} ; 70 \pm\right.$ $10 \mathrm{RH}$; 14-hour photophase), while on collard the period on fourth instar nymphs was lower than on third instar ones. The results reported by Shishehbor \& Brennan (1995) of E. formosa on Trialeurodes ricini (Misra) support our results. They demonstrated that the time required by E. formosa to complete the eggto-adult period on $T$. ricini was influenced by the host plant. Liu \& Stansly (1996) mentioned a slower development of the parasitoid $E$. pergandiella when the females oviposited on younger nymphs of $B$. tabaci B-biotype. This would probably allow whitefly development up to the third nymphal instar, thus ensuring suitable resources for the parasitoid larval development. We observed this same behavior for E. formosa.

The parasitoid selects the most suitable host instar for its reproduction, by lowering the mortality rate of the immature stages and increasing the chance for oviposition and host utilization. Younger host stages are more abundant and easy to find. However, younger stages have lower amounts of nutrients, thus slowering parasitoid immature development and increasing the time of exposition to negative environmental influences (Gerling, 1990). E. formosa prefers to parasitize third nymphal instar whitefly, but when these instars are absent the parasitoid oviposits on younger nymphs, causing their death and hindering the establishment of the host-parasite interaction (Gould et al., 1975).

\section{ACKNOWLEDGEMENTS}

To the "Conselho Nacional de Desenvolvimento Científico e Tecnológico (CNPq)" for financial supporting and for the scholarships granted to the second and the third authors.

\section{REFERENCES}

ALBERGARIA, N.M.S.; CIVIDANES, F.J. Exigências térmicas de Bemisia tabaci (Genn.) biótipo B (Hemiptera: Aleyrodidae). Neotropical Entomology, v.31, p.359-363, 2002.

ANTHONY, B.; PALANISWAMI, M.S.; HENNEBERRY, T.J. Encarsia transversa (Hymenoptera: Aphelinidae) development on different Bemisia tabaci Gennadius (Homoptera: Aleyrodidae) instars. Environmental Entomology, v.32, p.584-591, 2003. ARAKAWA, R. Reproductive capacity and amount of host-feeding of Encarsia formosa Gahan (Hymenoptera: Aphelinidae). Journal of Applied Entomology, v. 93, p.175-182, 1982.
BROWN, J.K.; FROHLICH, D.R. ; ROSSEL, R.C. The sweetpotato or silverleaf whiteflies: biotypes of Bemisia tabaci or a species complex? Annual Review of Entomology, v.40, p.511-534, 1995.

BURNETT, T. The effect of temperature on an insect host-parasite population. Ecology, v.30, p113-134, 1949.

COUDRIET, D.L.; PRABHAKER, N.; KISHABA, A.N.; MEYERDIRK, D.E. Variation in developmental rate of different hosts and overwintering of the sweetpotato whitefly, Bemisia tabaci (Homoptera: Aleyrodidae). Environmental Entomology, v.14, p.516-519, 1985.

GERLING, D. Natural enemies of whiteflies: predators and parasitoids. In: GERLING, D. (Ed.) Whiteflies: their bionomics, pest status and management. Andover: Intercept, 1990. p.147-158.

GOULD, H.J.; PARR, W.J.; WOODVILLE, H.C.; SIMMONDS, S.P. Biological control of glasshouse whitefly (Trialeurodes vaporariorum) on cucumbers. Entomophaga, v.20, p.285-292, 1975.

HODDLE, M.S.; DRIESCHE, R.G. van; SANDERSON, J.P. Biology and use of the whitefly parasitoid Encarsia formosa. Annual Review of Entomology, v.43, p.645-69, 1998.

HU, J.S.; GELMAN, D.B.; BLACKBURN, M.B. Growth and development of Encarsia formosa (Hymenoptera: Aphelinidae) in the greenhouse whitefly, Trialeurodes vaporariorum (Homoptera: Aleyrodidae): effect of host age. Archives of Insect Biochemistry and Physiology, v.49, p.125-126, 2002.

LIMA, L.H.C.; MORETZOHN, M.C.; OLIVEIRA, M.R.V. Survey of Bemisia tabaci (Gennadius) (Hemiptera: Aleyrodidae) biotypes in Brazil using RAPD markers. Genetics and Molecular Biology, v.23, p.1-5, 2000.

LIU, T.X.; STANSLY, P.A. Pupal orientation and emergence of some aphelinid parasitoids (Hymenoptera: Aphelinidae) of Bemisia argentifolli (Homoptera: Aleyrodidae). Annals of the Entomological Society of America, v.89, p.385-90, 1996.

OLIVEIRA, M.R.V.; HENNEBERRY, T.J.; ANDERSON, P. History, current status and collaborative research projects for Bemisia tabaci. Crop Protection, v.20, p.709-723, 2001.

SALAS, J.; MENDOZA, O. Biology of the sweetpotato whitefly (Homoptera: Aleyrodidae) on tomato. Florida Entomologist, v.78, p.154-160, 1995.

SHISHEHBOR, P.; BRENNAN, P.A. Parasitism of Trialeurodes ricini by Encarsia formosa: level of parasitism, development time and mortality on different host plants. Entomophaga, v.40, p.299-305, 1995.

SIMMONS, A.M. Settling of crawlers of Bemisia tabaci (Homoptera: Aleyrodidae) on five vegetable hosts. Annals of the Entomological Society of America, v.95, p.466-468, 2002.

SOTO, A.; NORERO, A.; APABLAZA, J.; ESTAY, Y.P. Requerimientos térmicos para el desarrollo de Encarsia formosa (Hymenoptera: Aphelinidae) criado en Trialeurodes vaporariorum (Hemiptera: Aleyrodidae). Ciencia e Investigación Agraria, v.28, p.103-106, 2001.

VILLAS BÔAS, G.L.; FRANÇA, F.H.; MACEDO, N. Potencial biótico da mosca-branca Bemisia argentifolii a diferentes plantas hospedeiras. Horticultura Brasileira, v.20, p.71-79, 2002.

WOETS, J.; LENTEREN, J.C. van. The parasite-host relationship between Encarsia formosa (Hymenoptera: Aphelinidae) and Trialeurodes vaporariorum (Homoptera: Aleyrodidae). VI. The influence of the host plant on the greenhouse whitefly and its parasite Encarsia formosa. West Paleartic Regional Section Bulletin, v.4, p.151-164, 1976.

Received May 25, 2007

Accepted March 13, 2008 